\title{
The binding of ethidium bromide with DNA: interaction with single- and double-stran ded structures
}

\author{
P.O. Vardevanyan ${ }^{1,3}$, A.P. Antonyan ${ }^{1}$ \\ M.A. Parsadanyan ${ }^{1}$, H.G. Davtyan ${ }^{1}$ and
} A.T. Karapetyan ${ }^{2}$

\author{
'Biophysics Department of the Biological \\ Faculty of Yerevan State University \\ 375025 Yerevan, Aleck Manoogian St. 1, Armenia \\ ${ }^{2}$ Physics Department \\ Yerevan University of Architecture \\ and Construction, 375009, Yerevan \\ Teryan St. 105, bld.2 \\ ${ }^{3}$ Corresponding author: Tel, 3741-57-10-61; \\ Fax, 3741-554-641; E-mail, simvar@arminco.com
}

Accepted 24 November 2003

Abbreviations: AMD, Actinomycin D; DAPP, 3,8-diamino-6-phenyphenantridine; ds-DNA, double stranded DNA; EtBr, ethidium bromide; NFC, non-fluorescence complexes; ss-DNA, single stranded DNA

\begin{abstract}
The pH-induced helix-coil transition of DNA and its complexes with EtBr is carried out at acidic $\mathrm{pH}$ in a wide interval of change of concentration ratio of EtBr/DNA. The binding isotherms of $\mathrm{EtBr}$ on double and single-stranded DNA at $\mathrm{pH}=7.0$ and $\mathrm{pH}=3.0\left(\mathrm{t}=25^{\circ} \mathrm{C}\right)$ are obtained by absorption and fluorimetric methods. Binding constants $(K)$ and number of bases ( $n)$, corresponding to one binding site were determined. Non fluorescent "strong" complex with ds-DNA at $\mathrm{pH}=7.0$ and $\mathrm{t}=25^{\circ} \mathrm{C}$ as well as "strong" and "weak" complexes with ss-DNA at $\mathrm{pH}=3.0$ and $\mathrm{t}=25^{\circ} \mathrm{C}$ are revealed.
\end{abstract}

Keywords: absorption isotherms in Scatchard's coordinates; acidic values of $\mathrm{pH}$; constants and number site sizes; $\mathrm{pH}$-induced denaturation; ss- and ds-DNA

\section{Introduction}

The existing data on interaction of $\mathrm{EtBr}$ with DNA specifies that this ligand can form several types of complexes with ds-DNA and ss-DNA (Karapetian et al., 1996, Vardevanyan et al., 2000). The conformation of ss-DNA basically is defined by intermolecular interactions between nitrogenous bases (stacking interaction, hydrogen bounds). Intermolecular binding in ssDNA are weaker, than in ds-molecules (Veselkov et al., 1997). It is necessary to note also, that the research of behaviour of ss-DNA in a solution is connected with certain difficulties. It is connected with occurrence of intermolecular as well as intramolecular binding in diluted solutions that carry in essential contribution to the enthalpy of intermolecular binding at $\mathrm{t}=25^{\circ} \mathrm{C}$ (Seanger, 1987; Graves, 1993). The earlier reported data showed a high affinity and selective binding of the antibiotic actinomycin $D$ (AMD) with ss-DNA. Ethidium Bromide (EtBr) also shows binding specificity with ss-oligonucleotide sequences (Veselkov et al., 1997, Vardevanyan et al., 2000). It is possible to assume that the selectivity complex formation of ligands with certain single-stranded sequences plays an important role in functioning of biologically active substances in processes connected with transcription and replication of DNA.

However, the binding of EtBr with ss-DNA is not clearly understood. Moreover, the possibility of interaction of EtBr with ss-DNA can occur by several modes (Tishchenko et al., 1996; Borisova et al, 1998). Existing experimental data for complex formation of EtBr with ss-polynucleotides are relevant to conditions, not excluding presence of ds-sites in DNA (Borisova et al, 1998).

Recently we obtained isotherms of EtBr adsorption on native and denatured poly(dA)-poly(dT) in the temperature interval of $20-70^{\circ} \mathrm{C}$. On the basis of data obtained, a model can be postulated in which the binding of $\mathrm{EtBr}$ with ss-polynucleotides at $70^{\circ} \mathrm{C}$ may cause stacking contacts between bases. The experimental data obtained specifies the presence of several ways of $\mathrm{EtBr}$ binding with ss-nucleic acids at high temperatures. On the other hand, the data avairable in the literature shows that an interaction of $\mathrm{EtBr}$ with ss-nucleic acids is basically carried out with synthetic polynucleotides. From this point of view the data of EtBr binding with heterogeneous ss-DNA can be very interesting and valuable. In this work, the investigation of behaviours of Ss-DNA was carried out at $\mathrm{t}=25^{\circ} \mathrm{C}$ and $\mathrm{pH}=3.0$ while the existence of ds-sites in DNA and its complexes with ligand is excluded. 


\section{Materials and Methods}

\section{Materials}

Ultrapure Calf Thymus DNA and EtBr ("Serva", Germany), $\mathrm{HCl}$ were used in this work. All preparations were used without additional purification. Concentration of used preparations was determined by absorption spectroscopy, using the values of molar extinction for calf thymus DNA $\varepsilon_{260}=6400 \mathrm{M}^{-1} \mathrm{~cm}^{-1}$ and EtBr- $\varepsilon_{480}=5600 \mathrm{M}^{-1} \mathrm{~cm}^{-1}$, respectively.

\section{Spectrophotometric measurements}

Fluorimetric and Spectrophotometric measurements were carried out on fluorimeter FluoroMax TM (France) and on spectrophotometers Pye Unicam-SP8-100 (England) and Specord M-400 (Germany).

All measurements were carried out in hermetic closed quartz cuvetts, with length of an optical way $1 \mathrm{~cm}$. pH-titration was carried out on ionomer-universal EV-74 (USSR). A solution of DNA was titrated by $0.2 \mathrm{~N} \mathrm{HCl}$ : each time $1 \mu \mathrm{l}$ of acid was added, mixed, then the value of $\mathrm{pH}$ was registered which is varied between \pm 0.02 units. The titration of $\mathrm{EtBr}$ solution with DNA is carried out by micropipette with volume of $10 \mu \mathrm{l}$ ("Hamilton"). All measurements were conducted at room temperature $\left(\mathrm{t}=25^{\circ} \mathrm{C}\right)$, at ionic strength of $\mu=2.0 \times 10^{-2} \mathrm{M}\left[\mathrm{Na}^{+}\right]$.

\section{Data analysis}

Spectrophotometric method of study of $\mathrm{pH}$-induced helix-coil transition of DNA/EtBr complexes, as in case of thermo-induced transition, is based on measurement of absorption spectra at $\lambda=260 \mathrm{~nm}$ with change of $\mathrm{pH}$ in the range of acidic values (Vardevanyan et al., 2001). For construction of helix-coil transition curves, the value of a degree of helixity-1- $\vartheta$ was used, appropriate to the given values of $\mathrm{pH}$ :

$$
1-\vartheta=\frac{A_{\rho \mathrm{H}}-A_{\text {heix }}}{A_{\text {coir }} A_{\text {helix }}}
$$

where $A_{\rho H}$ is the optical density of samples at the given value of $\mathrm{pH}, \mathrm{A}_{\text {nelix }}$ and $\mathrm{A}_{\text {coil }}$-the optical densities of samples at completely helix and coil conditions respectively. The values of $\mathrm{pH}$ corresponding to a point and interval of transition were determined by the same way as in the case of thermal denaturation. Quantity of bound molecules of EtBr with DNA was determined from the results of absorption and fluorimetric titration, as described in works (Borisova et al., 1998).

Adsorption isotherms were constructed in Scatchard's coordinates $r / C r r$, where $r$ is the number of bases complexed with $\mathrm{EtBr}, \mathrm{C}_{t}$ are the free (unbound) molecules of ligand in solution.
The binding curves of $\mathrm{EtBr}$ with DNA were constructed by formula:

$$
r / C_{t}=K(1-n r)\left[\frac{1-n r}{1-(n-1) r}\right]^{n-1}
$$

where $\mathrm{K}$ is binding constant, $\mathrm{n}$ - number of bases, corresponding to one binding site (Vardevanyan et al., 2000).

\section{Results}

Earlier, we carried out studies of $\mathrm{EtBr}$ interaction with ss-polynucleotides by denaturation of poly $(\mathrm{dA})$-poly(dT) at $\mathrm{t}=70^{\circ} \mathrm{C}$ and $\mathrm{pH}=7.0, \mu=2 \times 10^{-2} \mathrm{M} \mathrm{Na}^{+}$(Vardevanyan et al., 2000). However, a similar study on the complexes of EtBr with ss-DNA is complicated, as it is impossible to remain the complete isolation of system in these conditions. Therefore the addition of $\mathrm{EtBr}$ can result in formation of ds-sites, (as $\mathrm{EtBr}$ is the stabilizer of ds-DNA) that may distort the real situation.

To reveal the conditions, at which the complexes of DNA-EtBr in an interval of change of $r_{b}-0 \leq r_{b} \leq$ $0.5,\left(r_{b}=E t B r / D N A\right)$ are in ss-condition at $t=25^{\circ} \mathrm{C}$, we investigated the helix-coil transition induced by the change of environmental $\mathrm{pH}$ to the acidic range. On Figure 1, the curves of transition of DNA itself (1) and its complexes with $\mathrm{EtBr}(2-5)$ are given. As indicated from the given Figure, the width of an interval of transition $\mathrm{pH}$ of complexes increased at low concentrations of $\mathrm{EtBr}$, and shows the tendency to decrease when achieving certain value of ligand concentration. It indicates that during the denaturation of DNA there is a redistribution of ligand molecules from denatured (ssDNA) on native (not denatured yet-dsDNA) sites, as it takes place at thermo-induced transition (Vardevanyan et al., 2001). It is necessary also to note that the curves of transition of complexes are shifted in

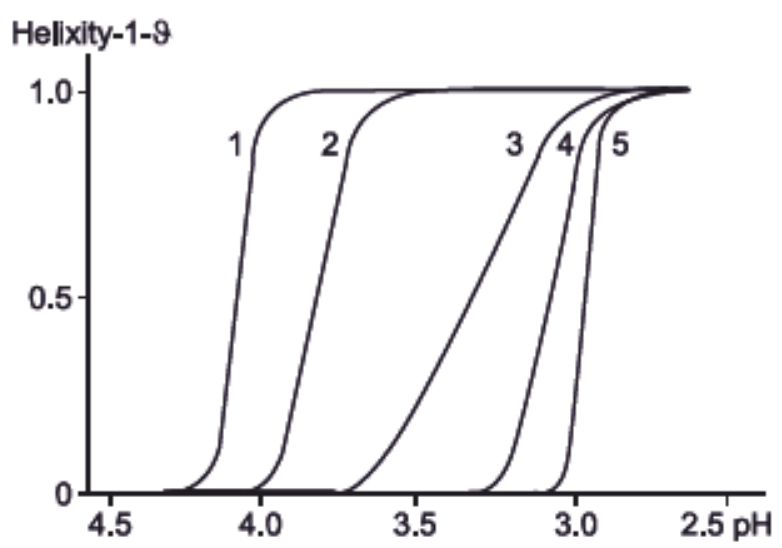

Figure 1. The pH-induced helix-coil transition of DNA itself (1) and its complexes with EIBr (2.5) in the interval of changes of $\mathrm{r}_{\mathrm{b}}-0 \leq \mathrm{r}_{\mathrm{b}}$ $\leq 0.5$, at $\mu_{\mathrm{Nat}}=2 \cdot 10^{-2} \mathrm{M}$. 

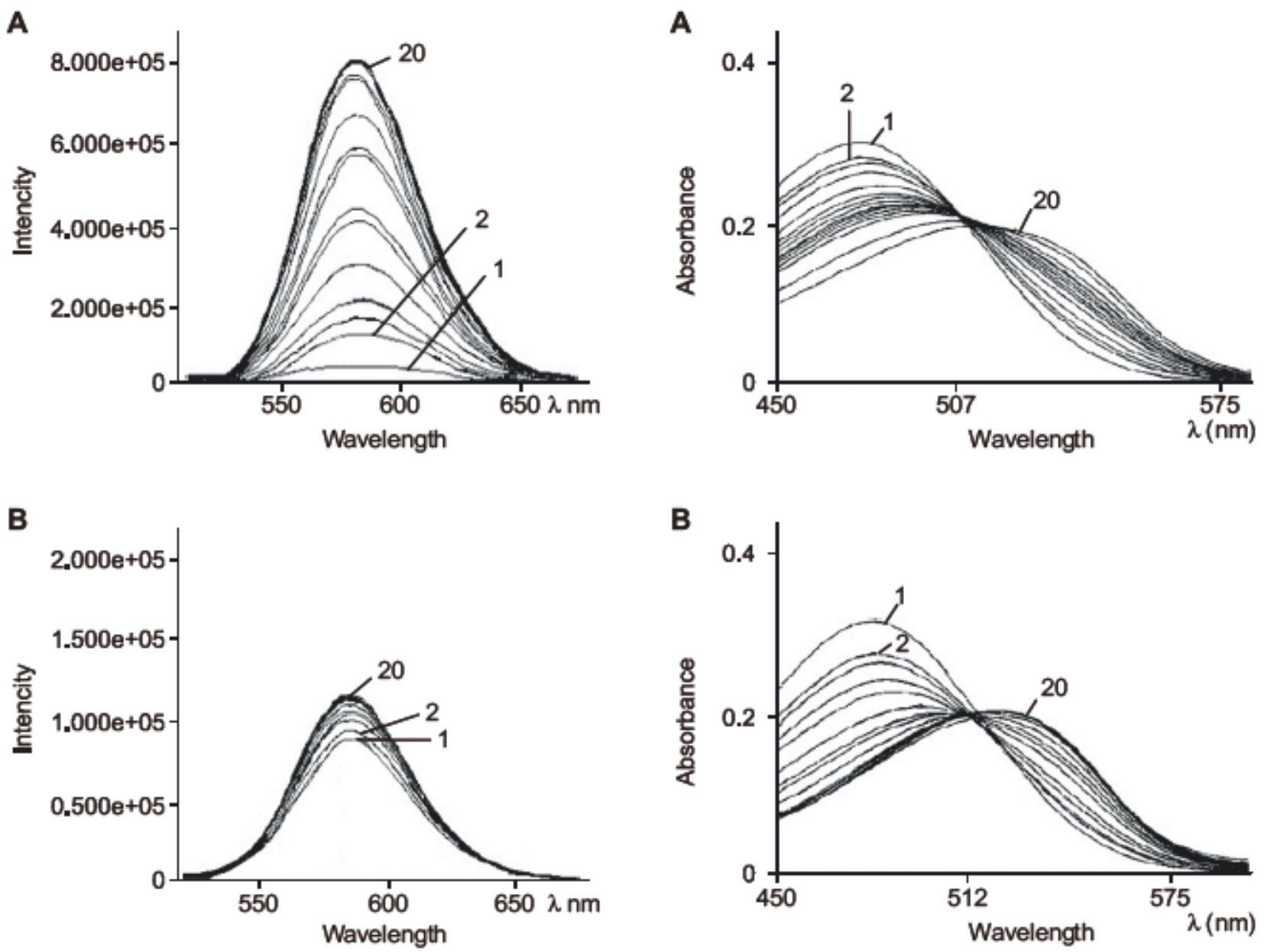

Figure 2. A. The fiuorescence spectra of $E B B$ (1) and its complexes with ds-DNA (2-15) at $\mathrm{pH}=7.0 ; \mathrm{t}=25^{\circ} \mathrm{C} ; \mu_{\text {sat }}=2 \cdot 10^{-2} \mathrm{M}$. The intensity of fuorescence spectra of complexes increase significantly in comparison with the intensity of $\mathrm{EBr}$ spectrum. B. The fuorescence spectra of EtBr (1) and its complexes with ss-DNA $(2-15)$ at pH $=3.0 ; \mathrm{t}=25^{\circ} \mathrm{C} ; \mu_{\text {nat }}=2 \cdot 10^{2} \mathrm{M}$. The intensity of fuorescence spectra of complexes increase insigniffcantly in comparison with the intensity of EtBr spectrum.

the range of low values of $\mathrm{pH}$ in comparison with the curve of DNA itself, that shows a stabilizing effect of $\mathrm{EtBr}$ on ds-structure of DNA (see the works (Cantor and Schimmel, 1980; Antonyan et al., 2001; Vardevanyan et al., 2001). Thus, complete denaturation of DNA and its complexes with $\mathrm{EtBr}$ occurs at $\mathrm{pH}=3.0$ and $\mathrm{t}=25^{\circ} \mathrm{C}$.

For the estimation of $\mathrm{EtBr}$ interaction with DNA the suitable values are the binding constant $(K)$ and number of binding site (n). Determination of these parameters allows an adequate description of various ligands influence on conformation and conformational transitions of DNA.

It was recently shown that $\mathrm{EtBr}$ could form at least three types of complexes with ds-DNA and two types with ss-DNA (Karapetian et al., 1996). The strong way

Figure 3. A. The absorption spectra of EtBr (1) and its complexes with ss-DNA $(2-15)$ at $\lambda=400-600 \mathrm{~nm}, \mathrm{pH}=3.0, \mathrm{t}=25^{\circ} \mathrm{C}, \mu_{\mathrm{kat}+}=$ $2 \cdot 10^{-2} \mathrm{M}$. The absorpton spectra of complexes decrease in maxima and are shitted in the range of high wavelengths in comparison with those of EtBr itself. There is the isosbestic point on spectra at $507 \mathrm{~nm}$, indicating that, in solution, the $\mathrm{EBr}$ molecules are in wo spectrophotometrically diferent conditions bound and unbound. B. The absorption spectra of EtBr (1) and its complexes with

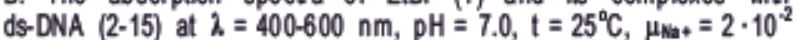
$M$. The absorption spectra of complexes decrease in maxima and are shifted in the range of high wavelengths in comparison with hose of EBr itself. There is the isosbesic point on spectra at $\lambda=512 \mathrm{~nm}$, indicating that, in solution, the EBr molecules are in wo spectropholometrically different conditions-bound and unbound.

of binding of EtBr with ds-DNA corresponds to intercalating mechanism of interaction and is characterized by high quantum yield of fluorescence (Borisova et al., 1998, Vardevanyan et al., 2002). On the other hand, Borisova et al. (1998) have shown that, except of strong fluorescent complexes, EtBr forms also strong non-fluorescence complexes (NFC).

With the purpose of finding out the contribution of NFC in binding parameters of EtBr with ss- and dsDNA, we carried out the spectroscopic (absorption 

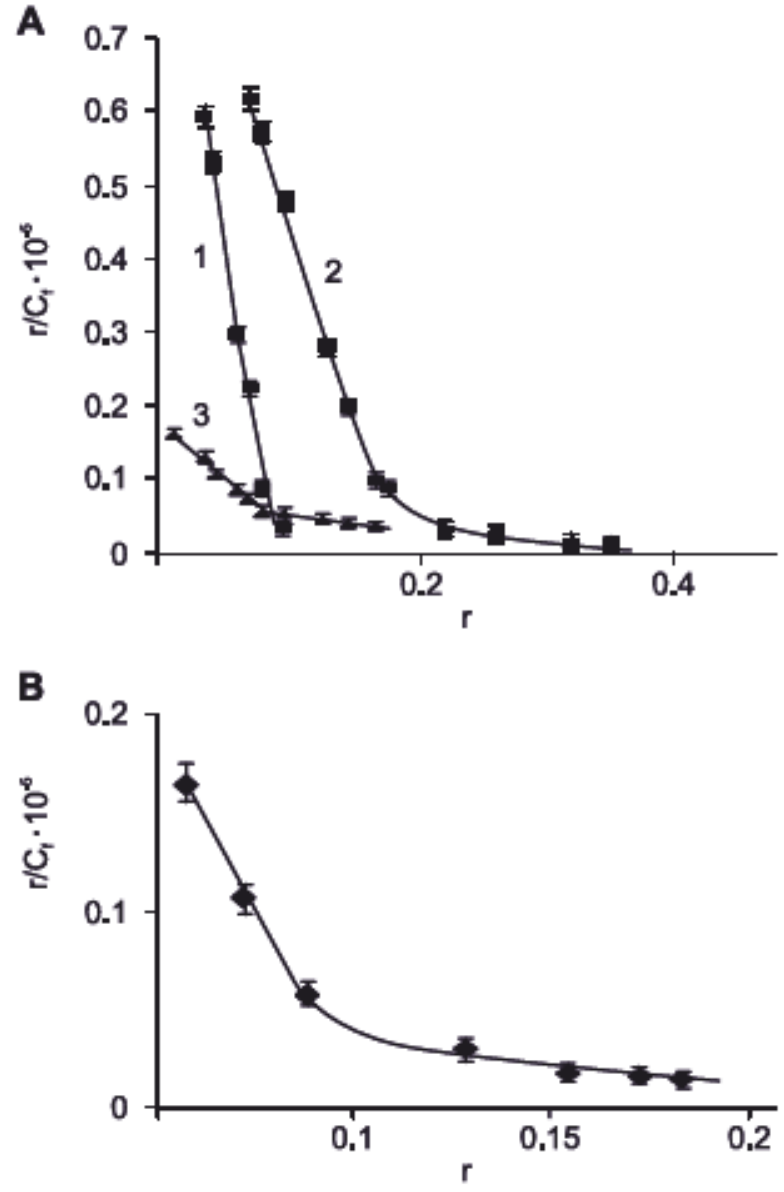

Figure 4. A. The binding curves of EBr with ds-DNA in Scatchard's coordinales, oblained from fluorimetric (1) and absorption spectra (2). Curve 3 is obtained by subtraction of curve 1 from curve 2 and corresponds to nonfluorescent complexes of EtBr with DNA at $\mathrm{pH}=7.0, \mathrm{t}=25^{\circ} \mathrm{C}, \mu_{\mathrm{Nat}}=2 \cdot 10^{2} \mathrm{M}$. B. The binding curves of EtBr with ss-DNA in Scatchard's coordinales, obtained at $\mathrm{pH}=3.0, \mathrm{t}=$ $25^{\circ} \mathrm{C}, \mu_{\text {nat }}=2 \cdot 10^{-2} \mathrm{M}$.

and fluorimetric) study of complexes at $\mathrm{pH}=7.0$ and $\mathrm{pH}=3.0$, at $\mathrm{t}=25^{\circ} \mathrm{C}\left(\mu=2.0 \cdot 10^{-2} \mathrm{M} \mathrm{Na}{ }^{\dagger}\right)$. In Figure 2, the spectra of fluorescence of EtBr complexes with ds-DNA $(\mathrm{A})$ at $\mathrm{pH}=7.0$ and with ss-DNA $(\mathrm{B})$ at $\mathrm{pH}$ $=3.0, \mathrm{t}=25^{\circ} \mathrm{C}$ are given. As shown in Figure 2, the intensity of fluorescence of complexes EtBr-ds-DNA at $\mathrm{pH}=7.0$ and $\mathrm{t}=25^{\circ} \mathrm{C}$ monotonously increases with decreasing of $\mathrm{r}_{\mathrm{b}}$ since more quantity of unbound ligand molecules intercalated between base pairs. On the other hand, possibility of the redistribution of bound non-intercalated molecules in intercalating sites is not excluded. Since saturation is observed on fluorescence spectra with a certain value of $r_{b}\left(r_{b} \leq 0.1\right)$, this may provide an evidence for the discontinuation of ligand molecule redistribution in intercalated sites. Figure 2B shows spectra of fluorescence of EtBr-ssDNA complexes at $\mathrm{pH}=3.0$ and $\mathrm{t}=25^{\circ} \mathrm{C}$. The inten-
Table 1. Experimental values of $K$ obtained fom binding curves of $\mathrm{EBr}$ with ds- and ss-DNA at $\mu=2.0 \cdot 10^{-2} \mathrm{M}\left[\mathrm{Na}^{+}\right], \mathrm{t}=25^{\circ} \mathrm{C}$.

\begin{tabular}{cc}
$\mathrm{DH}=7.0$ & $\mathrm{DH}=3.0$ \\
\hline $\mathrm{K}_{s^{\prime \prime}}=130 \cdot 10^{4} \mathrm{M}^{-1} \pm 0.10$ & $\mathrm{~K}_{s^{\prime}}=14 \cdot 10^{4} \mathrm{M}^{-1} \pm 0.10$ \\
$\mathrm{~K}^{\prime}=100 \cdot 10^{4} \mathrm{M}^{-1} \pm 0.18$ & \\
$\mathrm{~K}^{\mathrm{nf}}=30 \cdot 10^{4} \mathrm{M}^{-1} \pm 0.20$ & \\
$\mathrm{~K}_{\mathrm{w}}=3.7 \cdot 10^{4} \mathrm{M}^{-1} \pm 0.15$ & $\mathrm{~K}_{w^{\prime}}=2.3 \cdot 10^{4} \mathrm{M}^{-1} \pm 0.15$
\end{tabular}

$\mathrm{Ks}_{\mathrm{s}}$-the binding constant of EtBr with ds-DNA for "strong" complex received from absorption analysis. Kw"-the binding constant of EtBr with ds-DNA for "weak" complex received from absorption analysis. $\mathrm{K}_{\mathrm{s}}^{\mathrm{f}}$-the binding constant of EtBr with ds-DNA for "strong" complex received from fluorescent analysis. $\mathrm{K}_{\mathrm{s}}{ }^{\mathrm{H}}$-the binding constant of EtBr with ds-DNA for strong nonfluorescent complex received from absorpfon analysis. Ks'-the binding constant of EtBr with ss-DNA for "strong" complex received from absorption analysis. Kw'the binding constant of EBr with ss-DNA for "weak" complex received from absorption analysis. "s"-"strong", "w"-weak".

Table 2. Experimental values of $n$, obtained from binding curves EtBr with ds- and ss-DNA at $\mu=2.0 \cdot 10^{2} \mathrm{M}$ Na $7, \mathrm{t}=25^{\circ} \mathrm{C}$.

\begin{tabular}{cl}
\hline $\mathrm{DH}=7.0$ & $\mathrm{DH}=3.0$ \\
\hline $\mathrm{ns}^{\prime \prime}=9.0$ & $\mathrm{~ns}^{\prime}=8.0$ \\
$\mathrm{n}_{\mathrm{s}}{ }^{\mathrm{F}}=11.0$ & $\mathrm{n}_{\mathrm{w}}{ }^{\prime}=3.0$ \\
$\mathrm{~ns}^{{ }^{\mathrm{n}}}=8.0$ & \\
$\mathrm{n}_{\mathrm{w}}{ }^{\prime \prime}=3.0$ & \\
$\mathrm{n}_{\mathrm{w}}{ }^{{ }^{t}}=3.0$ &
\end{tabular}

$n_{s}$ "the value of $n$ for "strong" complex of EtBr with ds-DNA. $n_{s}{ }^{-}$-the value of $n$ for "strong" fuorescent complex of EtBr with ds-DNA. $\mathrm{ns}^{\mathrm{ni}}$-the value of $\mathrm{n}$ for "strong" nonfluorescent complex of EtBr with ds-DNA. ns'-the value of $n$ for "strong" complex of EtBr with ss-DNA. $n_{w}$ "the value of $n$ for "weak" nonfluorescent complex of EBr with ds-DNA. $n_{w}$-he value of $n$ for "weak" complex of EBr with ds-DNA. nw'the value of $n$ for weak complex of EtBr with ss-DNA. "s"-strong, "w"-weak.

sity of complex fluorescence depending on $\mathrm{r}_{\mathrm{B}}$ change altered insignificantly. In all probability, the quenching of $\mathrm{EtBr}$ fluorescence takes place, because the complete intercalation in ss-condition is impossible and ligand molecules become accessible for the molecules of water-active quenchers of fluorescence (Lakovich, 1985). For confirmation of the fact of binding of $\mathrm{EtBr}$ with ss-DNA, we carried out also spectrophotometric measurements of complexes in the same conditions, as in fluorimetric titration.

In Figure 3, the spectra of absorption of EtBr and its complexes with ss-DNA (A) at $\mathrm{pH}=3.0$ and ds-DNA (B) at $\mathrm{pH}=7.0, \mathrm{t}=25^{\circ} \mathrm{C}$, are given. As shown in Figure 3 , the absorption spectra of complexes depending on $r_{b}$ change decrease in maxima and are 
shifted in the range of high wavelengths in comparison with those of EtBr itself. Moreover, the isosbestic point was observed at $\lambda=507 \mathrm{~nm}$ indicating that the ligand molecules are in two spectrophotometrically distinguished condition - bound and free - as it occurs at $\mathrm{EtBr}$ interaction with ds-DNA (Figure 3B). Based on these data, it is possible to suggest that $\mathrm{EtBr}$ interact also with ss-DNA. This interaction, however, fails to be subjected to a quantitative estimation due to suppression of fluorescence.

A convenient method for obtaining of values of $K$ and $n$ is the Scatchard analysis-the construction of dependence of $r / C_{f}$ on $r$. The values of $r$ and $C_{f}$ are determined from spectra of absorption and fluorescence (see section Data analysis). Figure 4A shows the binding curve of $\mathrm{EtBr}$ with ds-DNA, received from spectra of fluorescence and absorption. Curve 1, obtained by the Scatchard-analysis of fluorescence spectra of EtBr-ds-DNA complexes, is linear, and corresponds to one, intercalation way of binding (Borisova et al., 1998). Curve 2, obtained from the analysis of absorption spectra, is nonlinear, and indicates that the molecules of $\mathrm{EtBr}$ cooperate with ds-DNA by more than one way. It is remarkable that these curves differ: the inclination of a binding curve of fluorescent molecules of $\mathrm{EtBr}$ (curve 1 ) is less than the inclination of a curve received from absorption spectra (curve 2). The subtraction of curve 1 from curve 2 results in a curve of EtBr binding with ds-DNA by the non-fluorescent way (curve 3 ), also given in Figure 4A. This curve is nonlinear and consists of two linear sites appropriate to strong and weak ways of binding.

Figure 4B shows the binding curve of $\mathrm{EtBr}$ with ss-DNA, received at $\mathrm{pH}=3.0, \mathrm{t}=25^{\circ} \mathrm{C}$. In the work (Karapetian et al., 1996), theoretical calculations reveal that $\mathrm{EtBr}$ can interact with ss-DNA at least by two independent ways. We therefore analyzed the received curve, based on this reason.

\section{Discussion}

The effectiveness of most drugs that exert their biological activity by direct binding to DNA is due to their ability to form the covalent and non-covalent complexes with polynucleotide (Haroutiunian et al., 1998). They may locally blockade or initiate replication and transcription of DNA by intercalating and poisoning topoisomerases or by binding in the minor groove and inhibiting transcription (Searcey et al., 1998). The researches on the ligand interaction with DNA at acidic $\mathrm{pH}$ draw special interest intriguing fact that protonation specifically affects the structure of biopolymer. It is known, that at acidic $\mathrm{pH}$, the double-stranded DNA is denatured. However, at one-half an equivalent of $\left[\mathrm{H}^{*}\right]$ protons bound per Cytosine $(\mathrm{C})$ base residues, there is an extremely sharp transition to the acidic helix form $\mathrm{C}-\mathrm{H}^{*}-\mathrm{C}$. If more protons are added, this helix becomes destabilized, and future titration eventually converts it into two single-stranded, fully protonated poly $\mathrm{CH}^{*}$. The acid double helix of poly(A) also is not a fully protonated form. However, the protons added to $\operatorname{poly}(\mathrm{A})$ are not directly involved in base pairing. The acid form becomes stable relative to single strands at degrees of proton uptake far less than one per $\mathrm{A}$ residue. The further reduction of $\mathrm{pH}$ results in destabilization of these structures and formation of one-stranded helixes with protonated bases $\mathrm{AH}^{*}$ and $\mathrm{CH}^{*}$ (Cantor and Schimmel, 1980). It is obvious that the protonation of bases brings about an increase of a total positive charge, resulting in somewhat different interaction between positively charged ligands rather, than at neutral values of $\mathrm{pH}$.

Taking into account the above mentioned, acidic values of $\mathrm{pH}$ were chosen as the factor of an environment for research of $\mathrm{EtBr}$ interaction with ss-DNA. However, it is necessary to consider $\mathrm{pK}_{\mathrm{a}}$ of ligand. It is known that $\mathrm{pK}_{\mathrm{a}}$ of analogue of EtBr-3,8-diamino-6phenylphenantridine (DAPP) remains constant at given ionic strength, and the optical characteristics of this compounds coincide with those for $\mathrm{EtBr}$ at neutral, as well as at acidic values of $\mathrm{pH}$, therefore we did not control this parameter (Jones and Wilson, 1981).

The analysis of binding curve of $\mathrm{EtBr}$ with ds-DNA, given on Figure $4 \mathrm{~A}$ reveals that this ligand binds with ds-DNA at least by three ways. It specifies that the binding curves of $\mathrm{EtBr}$ with ds-DNA received from fluorescence and absorption spectra are differed (curves 1 and 2). This distinction is caused by the presence of non-fluorescent molecules of $\mathrm{EtBr}$ on ds-DNA. From binding curves 1 and 2 the values of $\mathrm{K}$ are acquired by two independent methods, generalized in table 1 . The values of $\mathrm{Ks}_{\text {s }}$ obtained from curve 1 and 2 (Figure 4A) differ whilst $K_{s}^{\prime}<K_{s}$ (where $\mathrm{K}_{s}{ }^{\mathrm{t}}$ is binding constant of fluorescent molecules of $\mathrm{EtBr}, \mathrm{K}_{s}$-constant of binding of $\mathrm{EtBr}$ with ds-DNA, obtained by absorption method). This distinction is due to as they can bind with ds-DNA by two various ways. Values of $K_{s}$, obtained from a binding curve 2 (Figure 4A), corresponds to strong fluorescent and strong non fluorescent (semi-intercalating) types of EtBr binding with ds-DNA, since $\mathrm{Ks}^{\mathrm{wt}}$, acquired from a binding curve 3 (Figure 4A), coincides with a differ-

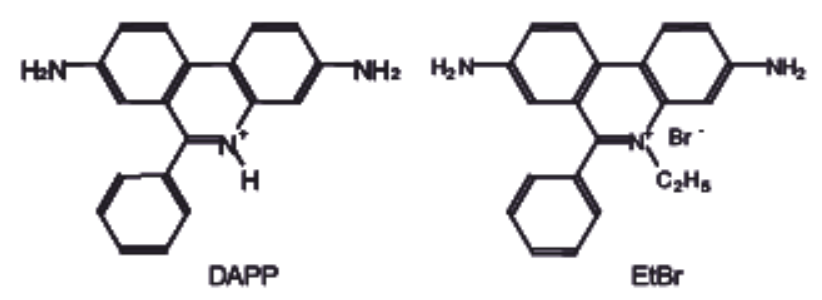


ence $\mathrm{K}_{s}-\mathrm{K}_{s}^{\prime}$. The analysis of binding curves of $\mathrm{EtBr}$ with ss-DNA reveals that this ligand binds with ss-DNA at least in two ways, one of which is strong, $\mathrm{Ks}^{\prime} / \mathrm{Kw}_{\mathrm{w}}$ - 10 (Ks' corresponds to the "strong" binding constant with ss-DNA, Kw' the same parameter corresponding to the weak interaction) as it was predicted in the work (Karapetian et al., 1996) and, on the other hand, the value of $\mathrm{Ks}^{\text {nt }}$ practically coincides with one received at $t=70^{\circ} \mathrm{C}$ (Vardevanyan et al., 2000). It specifies that this type of binding has an intercalation nature, though the mechanisms of influence of $\mathrm{pH}$ as well as temperature essentially differ from each other. Moreover, the value of $\mathrm{K}_{s}$, appropriate to non-fluorescent strong complex of $\mathrm{EtBr}$ with ds-DNA coincides with those received for complexes of EtBr-ss-DNA $\left(\mathrm{Ks}^{\prime \prime \prime} / \mathrm{K}^{\prime} \approx 2\right)$. The values of $\mathrm{Kw}^{\mathrm{m}}$ and $\mathrm{Kw}^{\prime}$ also are in good accordance (see Table 1). In the work (Wadkins et al., 1996) is shown that actinomycin D (AMD) interacts with ss-polynucleotides. Moreover, aromatic ring of AMD is partially inserted in a plane between the neighbor bases, i.e. semi-intercalated in a molecule of ss-DNA. In this work is shown also that AMD interacts with ss-DNA by several ways. The work (Karapetian et al., 1996) reveals the possibility of binding of $\mathrm{EtBr}$ and $\mathrm{AMD}$ with DNA by several types and the thermodynamic parameters of binding of these ligands with ds- and ss-DNA practically coincide. Therefore, EtBr, as well as AMD, will bind with ss-DNA in more than one way, where a "strong" way is of an intercalative nature.

Thus, the obtained values of $\mathrm{K}$ revealed, that $\mathrm{EtBr}$ may interact both with ds- and ss-sites of DNA (Antonyan et al., 2001; Vardevanyan et al., 2001). It is reasonable to assume that a non-fluorescent strong complex both with ds-, and ss-DNA is formed by partial intercalation of $\mathrm{EtBr}$ molecules into a plane of the neighbor bases of one strands of DNA. Most probably, the phenantridine ring of $\mathrm{EtBr}$ inserted in one of ds-DNA grooves (Karapetyan et al., 2001), and becomes accessible to molecules of water - intensive quenchers of fluorescence (Lakovich, 1985).

The acquired values of a number of base pairs $n$ reveal, that the $n_{s}{ }^{\prime}$ for fluorescent molecules of $\mathrm{EtBr}$ exceeds the value of $n_{s}$, appropriate to a "strong" mode of EtBr binding with ds-DNA and that received from absorption analysis (Table 2). It specifies that while intercalating the number of binding sites is limited, than in the other ways of interaction. The value of $n_{\mathbf{s}}$, obtained for interaction of $\mathrm{EtBr}$ with ss-DNA, coincides with this parameter obtained for non-fluorescent molecules of EtBr on ds-DNA that indicates the similarity of binding sites. The values of $\mathrm{n}_{\mathrm{w}}$ are identical for "weak" binding type both for dsand ss-DNA, as they correspond to electrostatic (weak) type of interaction with phosphate groups of DNA (Table 2). The value of $n_{w}$ is half that of the $\mathrm{ns}$ and corresponds to electrostatic mechanism of interaction of positive charged molecules of $\mathrm{EtBr}$ with negatively charged phosphate groups of DNA. This fact indicates that those electrostatic binding sites are more accessible for molecules of ligand. From this point of view it is necessary to note that phosphate groups of DNA at $\mathrm{pH}=3.0$ are protonated particularly and in neutral conditions these groups are nearly fully disprotonated (Seanger, 1987). Therefore, the possibility of electrostatic interaction between ligand molecules and DNA can not be ruled out.

Thus, on the basis of the obtained results it is possible to suggest that strong non-fluorescence complexes of EtBr with ds-DNA correspond to strong semiintercalating complexes with ss-DNA. It is necessary also to note that NFC plays an important role in stabilizing of ds-structure of DNA, that was not taken into account in earlier works. On the other hand, the binding of EtBr with ss-DNA does not depend on factors of the environment (temperature, $\mathrm{pH}$ ).

The presented data can be useful in understanding of mechanisms of interaction of various drugs with DNA in processes of metabolism of a cell and the organisms as a whole, and also by development of new medicinal preparations.

\section{References}

Antonyan AP, Vardevanian PO, Karapetian AT. pH-induced hellx-coil transition of EtBr-DNA complexes. J Biomol Struct Dyn 2001;18:917-8

Antonyan AP, Vardevanian PO, Karapetian AT. Interaction of EtBr with ss-DNA under influence of Medium Factors. Problems of Biochemistry, Radiation and Space Biology. II International symposium under the auspices of UNESCO dedicated to the memory of academician N.Sissakian and II SISSAKIAN READINGS. Moscow, Dubna. 2001. Book of Abstracts, 58.

Borisova OF, Shchiolkina AK, Karapetyan AT, Surovaya AN. The heterogeneity of strong binding site of ethidium bromide on DNA. Fluorescent and non-fluorescent complexes. Molecular Blology (Rus) 1998;32:855-62

Cantor CR, Schimmel PR. Biophysical Chemistry, W.H. Freeman and company, New York, Book 1980;3:1371

Graves DE. Sequence selective binding of Actinomycin D to duplex and single-stranded DNA. Book of Abstracts. Workshop on DNA-Drug Interactions. Madrid 1993;15-17:39

Haroutiunian SG, Dalian EB, Morozov VF, Mamasakhlisov ESh, Shahinyan MS, Akhrem AA, Lando DYu, Messori L, Orili P. Influence of cis- and trans-DDP binding on hellx-Coil transition of DNA's with Different GC-content. Inorg Chemica Acta $1998 ; 275-276: 510-4$

Jones RL, Wilson WD. Effect of ionic strength on the $\mathrm{pK}_{\mathrm{a}}$ of ligands bound to DNA. Biopolymers 1981;20:141-54

Karapetian AT, Mehrabian NM, Terzikian GA, Vardevanian 
PO, Antonian AP, Borisova OF, Frank-Kamenetskii MD. Theoretical treatment of melting of complexes of DNA with ligands having several types of binding sites on helical and single-stranded DNA. J Biomol Struct Dyn 1996;14:275-83

Karapetyan AT, Boyagyan ZR, Manukyan GA, Antonyan AP, Vardevanyan PO, Borisova OF. Strong and weak interaction of Ethidium bromide with ds-DNA. J Biomol Struct Dyn 2001;18:918

Lakovich J. Principles of fluorescence spectroscopy. Plenum Press, 1985

Malahti R, Natarajan G, Holler E. Helix-Coil transition in DNA by novel Pt (II) complexes: A pH melting study. J Biomol Struct Dyn 1998;15:1173-80

Seanger W. Principles of nucleic acid structure, 1984, Springer Verlag, New York, NY

Searcey M, McClean S, Madden B, McGown AT, Wakelin PG. Synthesis, DNA-cleaving properties and cytotoxicity of intercalating chelidamic acid derivatives. Anti-Cancer Drug Design 1998; 13:837-55

Tischenko EI, Karapetian AT, Borisova OF. The heterogen complexes of EtBr and their role in stabilizing of $(\mathrm{dA})_{\mathrm{n}}-(\mathrm{dT})_{\mathrm{n}}$. Molecular Biology (Rus) 1996;30:1370-7
Vardevanyan PO, Antonyan AP, Manukyan GA, Karapetyan AT, Shchiolkina AK, Borisova OF. Binding of $\mathrm{EtBr}$ with native and denaturated poly(dA)-poly(dT). Molecular Blology (Rus) $2000 ; 34: 310-5$

Vardevanyan PO, Antonyan AP, Manukyan GA, Karapetyan AT. Study of ethidium bromide interaction peculiarities with DNA. Exp Mol Med 2001;33:205-8

Vardevanyan PO, Antonyan AP, Minasbekyan LA, Karapetyan AT. Some aspects of DNA-EtBr interaction peculiarities. The Genome and Beyond Structural Biology for Medicine. (Proceedings of the 2002, Miami Nature Biotechnology Winter Symposium), The Scientific World 2002;2: 144-5

Veselkov AN, Baranovski SF, Dimant LN, Petrenko NV, Veselkov DA, Taker A, Devis D. The complex-formation of ethidium bromide with single-stranded non-complementary deoxytetranucleotide 5'-d(ApApGpC). Molecular Biology (Rus) $1997 ; 31: 263-73$

Wadkins RM, Jares-Erijman EA, Klement R, Rudiger A, Jovin TM. Actinomicin D binding to single-stranded DNA: sequence specificity and hemi-intercalation model from Fluorescence and ${ }^{1} H$ NMR Spectroscopy. J Mol Biol 1996;262:53-68 